\title{
Effects of Echoic Teaching Combined with Basic Reading Repertoires on Word Naming in Children with Intellectual Disabilities
}

\author{
Máyra Laís de Carvalho Gomes ${ }^{1}$ \\ Priscila Benitez \\ Universidade Federal de São Carlos, São Carlos, SP, Brazil \\ Camila Domeniconi \\ Departamento de Psicologia da Universidade Federal de São Carlos, São Carlos, SP, Brasil \\ Ana Claudia Moreira Almeida Verdu \\ Universidade Estadual Paulista - Bauru, SP, Brasil
}

\begin{abstract}
The basic discriminative repertoires may be considered important prerequisite for reading acquisition. This study investigated the influence of the gradual teaching of discriminative repertoires prior to reading on the acquisition of this skill in children with intellectual disabilities, emphasizing the echoic teaching combined with figure naming. Participants were two children with Down syndrome and intellectual disabilities, with difficulties in vocalization. Relationships between stimuli were taught based on the selection of figures and printed words when presented with dictated words; and between stimuli and responses, such as echoing according to the dictated word, picture naming and constructing the printed word. After this teaching procedure, the naming of printed words and the equivalence relations between printed word and picture and vice versa were tested. Their performances in the emerging relational tasks increased from a mean of $45 \%$ correct evaluated in the pre-test to the mean of $77 \%$ correct in the posttest. Participants who had previously null repertoires of word naming started reading. Echoic teaching could assist in more accurate naming of printed words and the gradual teaching of basic relational skills of naming provided the expansion of this repertoire.
\end{abstract}

Keywords: Word naming, equivalence relations, echoic, intellectual disability.

\section{Efeitos do Ensino do Ecoico Aliado a Repertórios Básicos de Leitura sobre a Nomeação de Palavras em Crianças com Deficiência Intelectual}

\section{Resumo}

Os repertórios discriminativos básicos podem ser considerados importantes pré-requisitos para a aquisição da leitura. O presente trabalho verificou a influência do ensino gradual de repertórios discriminativos prévios ao repertório de leitura sobre a aquisição desta habilidade para crianças com deficiência

Mailing address: Rua Amazonas, no 2534, Marques, Teresina, PI, Brazil 64003-170. E-mail: mayra.lais@, hotmail.com, pribenitez@yahoo.com.br, camila@ufscar.br and anaclaudiaverdu@gmail.com

Financing: Bolsa de Mestrado e Doutorado Coordenação de Aperfeiçoamento de Pessoal de Nível Superior (CAPES).

All authors are members of the Instituto Nacional de Ciência e Tecnologia - Comportamento, Cognição e Ensino (INCT-ECCE), coordinated by Dr. Deisy G. De Souza, with funding from CNPq (process \# 573972 / 2008-7) and FAPESP, (Process \# 2008 / 57705-8). 
intelectual, destacando o ensino de ecoico aliado à nomeação de figuras. Participaram duas crianças com Síndrome de Down e deficiência intelectual, com dificuldades para oralizar. Foram ensinadas relações entre estímulos baseadas em seleção de figuras e palavras impressas mediante palavra ditada; e entre estímulos e respostas como ecoar conforme palavra ditada, nomear figuras e construir palavra impressa. Após este ensino foram testadas a nomeação das palavras impressas e as relações de equivalência entre palavra impressa e figura e vice versa. Os desempenhos nas tarefas relacionais emergentes passaram de $45 \%$ de acertos, em média, avaliados no pré-teste, para a média de $77 \%$ de acertos no pós-teste. Os participantes que antes apresentavam repertório nulo de nomeação passaram a ler. O ensino de ecoico pôde auxiliar na nomeação mais precisa de palavras impressas e o planejamento gradual do ensino de habilidades relacionais básicas de nomeação proporcionou a ampliação deste repertório.

Palavras-chave: Nomeação de palavras, relações de equivalência, ecoico, deficiência intelectual.

\section{Efectos de la Enseñanza del Ecoico Asociada a Repertorios Básicos de Lectura sobre el Nombramiento de Palabras en Niños con Discapacidad Intellectual}

\section{Resumen}

Los repertorios discriminativos básicos pueden ser considerados importantes requisitos para la adquisición de la lectura. Este estudio investigó la influencia de la enseñanza gradual de repertorios discriminativos previos al repertorio de lectura sobre la adquisición de esta habilidad para niños con discapacidad intelectual, destacando la enseñanza de ecoicos asociada al nombramiento de imágenes. Participaron dos niños con Síndrome de Down y discapacidad intelectual, con dificultades para oralizar. Se les enseñaron relaciones entre estímulos basadas en selección de imágenes y palabras mediante palabra dictada; y entre estímulos y respuestas como hacer eco según la palabra dictada, nombrar imágenes y construir palabra impresa. Terminada la etapa de enseñanza, se pusieron a prueba el nombramiento de las palabras impresas y las relaciones de equivalencia entre palabra impresa e imagen y viceversa. Los desempeños en tareas relacionales emergentes aumentaron de $45 \%$ de aciertos, en media, evaluados en la prueba previa, a la media de $77 \%$ de aciertos en el post-test. Los participantes que presentaban repertorio nulo de nombramiento empezaron a leer. La enseñanza de ecoicos puede contribuir para el nombramiento más preciso de palabras impresas y la planificación gradual de la enseñanza de habilidades relacionales básicas de nombramiento proporcionó la expansión de este repertorio.

Palabras clave: Nombramiento de palabras, relaciones de equivalencia, ecoico, discapacidad intelectual.

According to de Rose (1993), the act of reading can be broken down into smaller repertoires, described by relationships between stimuli and between stimuli and responses, and related by equivalence classes, thus forming a network of relationships: some directly taught and others emerging from this teaching. The paradigm of stimulus equivalence describes the conditions under which stimuli start to form equivalence classes. The operating criteria start from assumptions of substitutability between formally different stimuli (de Rose \& Bortoloti, 2007; Sidman, 1994; Sidman \& Tailby, 1982).
The equivalence relations are identified when relationships between members of a stimulus class demonstrate the three formal defining properties of equivalence: reflexivity, symmetry and transitivity (Sidman \& Tailby, 1982; Sidman, Wynne, Maguire, \& Barnes, 1989). Thus, the reflexive properties are those which are maintained between a term and itself (e.g., $\mathrm{A}=\mathrm{A}$ ); the symmetric properties are those in which the order of the terms is reversible (e.g., if $\mathrm{A}=\mathrm{B}$, then $\mathrm{B}=\mathrm{A}$ ); and the transitive properties are those in which the common terms in two ordered pairs determine a 
third ordered pair (e.g., if $\mathrm{A}=\mathrm{B}$ and $\mathrm{B}=\mathrm{C}$ then $A=$ C.). (Catania, 1999, p. 166)

Among the many investigation possibilities, this paradigm can be adopted for the study of reading behaviors, such as: to emit a verbal response when presented with a printed word (textual behavior that can also be called decoding or printed word naming) and the behavior of reading with comprehension (behavior, for example, of relating figures to printed words and vice versa). The same textual stimulus is provided for both the emission of a verbal response and for the selection of a figure; and different learning procedures, such as those involving the establishment of the network of equivalence relations, can be planned in an attempt to ensure the learning of basic skills prior to the naming of words, in order to facilitate their subsequent acquisition.

The network of equivalence relations can be established through conditional discriminations, in which a stimulus sample serves as an occasion for choosing one of the comparison stimuli. Some relational tasks comprise the network of relationships involved in the naming of a printed word. These are the identity tasks between figure-figure (BB) and between printed wordprinted word (CC), those of figure naming (BD), those of auditory-visual selection, such as between dictated word-figure $(\mathrm{AB})$ and between dictated word-printed word (AC), those of visual-visual selection, such as between figureprinted word (BC) and between printed wordfigure (CB), those of copying by composition of smaller units (CE) and by manuscript (CF) and dictation by composition of smaller units (AE) and by manuscript (AF). Simply put, if a competent speaker and listener selects a figure when presented with a printed word (CB) and names that figure (BD), the naming of words (CD) will be easily demonstrated, as the control exercised by the figure stimulus (B) on the verbal response (D) will be transferred to the printed word (C). Other relationships may offer additional elements for the establishment or transference of stimulus control. For example, echoing dictated words (AD) is an important prerequisite for naming of either printed words or figures to emerge.

The advantage of using the network of relationships in order to comprehend and teach reading behavior is based on the possibility of breaking down complex tasks into simpler tasks, facilitating the process of evaluation and teaching-learning of the naming repertoire (e.g. Fonseca, 1997; Melchiori, de Souza, \& de Rose, 2000). This form of evaluation and teaching of basic repertoires for reading has been adopted with participants with different special educational needs, such as hearing impairment and use of frequency modulation system (Bevilacqua \& Souza, 2012), deaf people who communicate in LIBRAS (Pereira \& Almeida-Verdu, 2012), subjects with auditory deficiencies and cochlear implants (Santos, 2012) and with visual impairments (Quinteiro, 2014), demonstrating which relationships are already well established and which should be the teaching target in these learners.

The simplest processes and precursor skills of learning a new repertoire are considered by Sidman (1977) as important prerequisites for the acquisition of naming. Any weaknesses in the learning of individuals should be attributed to the inadequacy of the procedures and not the intrinsic characteristics of the student or of the environment from which they come (de Rose, 2005). The model of equivalence relations has outlined teaching procedures and structures with demonstrated ability to manage some of the difficulties of the learning process (e.g. de Rose, de Souza, Rossito, \& de Rose, 1989; de Souza \& de Rose, 2006; Sidman, 1994, Stromer, Mackay, \& Stoddard, 1992). A program teaching the naming of printed and written words (ProgLeit ${ }^{\circledR}$ ), based on the paradigm of stimulus equivalence, was designed to evaluate and teach this network of relationships in small steps and in an individualized way (de Souza \& de Rose, 2006; Rosa, de Rose, de Souza, Hanna, \& Fonseca, 1998).

The study by Melchiori et al. (2000) reports the application of the reading program (ProgLeit $®)$ in different populations with difficulties in learning to name printed words, 
such as pre-school students, students of the first grade of regular education, students with overall developmental delay and illiterate adults. It was based on the teaching of conditional discriminations between the dictated word and the printed word and on the teaching of the construction (copy) of printed words from the selection of the component letters or syllables of the words taught. From this procedure, all the students learned to read the training words and, with few exceptions, the generalization words derived from the recombination of the smaller units of the words taught. However, the students with overall developmental delays presented difficulty in the generalized reading and required a greater number of sessions and the inclusion of remediation procedures to learn to read the training words.

From the analysis of the difficulties that were encountered with the participants of the study of Melchiori and colleagues (2000) and other participants with intellectual disabilities in later studies (e.g. de Freitas, 2009, 2012) and considering the advantages of direct teaching of the echo repertoire for the subsequent response of naming of figures (e.g. AlmeidaVerdu, Bevilacqua, de Souza, \& Souza, 2009; Souza, Almeida-Verdu, \& Bevilacqua, 2013), the present study included echoic teaching as one of the stages of the procedure to verify the effects of this teaching on the target repertoire (naming printed words).

The training of expressive repertoires, such as to echo and name figures, can improve the intelligibility of the speech of participants. The intelligibility of the speech, considered in the scope of this study as the point to point correspondence between the vocal emission of the participant and the conventions established by the verbal community, is seen to be inconsistent in participants with characteristics of a repertoire consistent with the diagnosis of intellectual disability. In general, word imitation teaching procedures (echoic verbal operant) have been effective in the subsequent response of naming of figures (Almeida-Verdu et al., 2009; Souza et al., 2013) and of naming of printed sentences (Golfeto \& de Souza, 2015) in populations with different special educational needs. On the other hand, greater accuracy of speech production (more intelligible speech) in printed word naming tasks has been obtained after exposure to teaching programs based on the equivalence relations model, when they promote control by units smaller than the word, coupled with successive opportunities to verbalize (Almeida-Verdu et al., 2015; Anastácio-Pessan, Almeida-Verdu, Bevilacqua, \& de Souza, 2015; Neves \& Almeida-Verdu, 2014), however, these participants were already rudimentary readers.

Considering that the oral emission of a word when presented with a sample of the same type (AD) may be a simpler repertoire, in contrast to decoding the printed word (CD), and considering the need for further investigation of the use of procedures based on the paradigm of stimulus equivalence for teaching word naming to participants with intellectual disabilities, this study aimed to verify the influence of the gradual teaching of discriminative repertoires prior to the establishment of equivalence classes, including the echoic verbal operant, on the emergence of naming of printed words for two children with intellectual disabilities and verbalizing difficulties.

\section{Method}

\section{Participants}

Two learners with Down syndrome and intellectual disabilities attending a special private school in the state of São Paulo participated in the study. These participants were illiterate, were aged 8 (A1) and 11 years (A2) and were chosen, mainly, because they had not learned naming in another study (Gomes, 2014) and presented difficulties verbalizing.

The learners, A1 and A2, were selected due to presenting mean emerging relational performance $\left(\mathrm{BC} / \mathrm{CB}^{2}\right)$ below $30 \%$ in the Reading

\footnotetext{
To relate a printed word corresponding to a sample figure, as well as relate a figure corresponding to a printed word sample, without direct training.
} 
and Writing Diagnosis ${ }^{3}$ and presenting zero repertoire in naming of printed words (CD). In addition to these criteria, the learners had daily attendance in school activities, thus were able to maintain high frequencies in the experimental sessions, since they were held at the school.

The families of the selected learners previously authorized their participation in the study, through the Terms of Consent ${ }^{4}$. The repertoire of the learners was characterized by consulting the diagnosis chart, present in the school, and by the application of the Wechsler Intelligence Scale for Children (WISC-III) - Third Edition (Wechsler \& Figueiredo, 2002) and the Peabody Picture Vocabulary Test (PPVT-R) - Revised (Dunn \& Dunn, 1981) in order to map the level of cognitive development and receptive vocabulary of each. These data are shown in Table 1.

\section{Experimental Situation}

Data collection occurred in a classroom in a special private school in the city of São Carlos, Brazil. The room was well lit and had a bookshelf with books and two tables with chairs. The site was previously prepared by the experimenter, in order to reduce the intervening variables, such as distracting stimuli, external noise and light.

This experimental environment was organized so that the learner could perform computerized tasks that would facilitate the teaching of paired relationships between auditory and/or visual stimuli. The participants were taken individually to the collection environment and, in front of the computer, were directed in the performance of the learning steps. The experimenter stayed next to the learner for every task.

The teaching sessions occurred five days a week for each learner. The limit for the implementation of the teaching steps per session depended on the student's motivation for the

3 Evaluation of the repertoire of reading and writing through relational tasks that use discrimination processes and comprise the network of equivalence relations (Fonseca, 1997).

4 This study was approved by the Human Research Ethics Committee of the Federal University of São Carlos, under authorization No. 112.504/2012. teaching and their learning performance during the procedure. Generally, they were exposed to a maximum of three consecutive steps per session, which determined the average duration of a maximum of 30 minutes per session, and then they returned to the classroom.

\section{Instruments and Materials}

For the application procedure, a camcorder, a laptop computer and the WISC-III and PPVT-R psychological tests, were used. The Windows platform and the "Learning to read and write in small steps" software (Rosa et al., 1998), known as the Reading Program (ProgLeit ${ }^{\circledR}$ ), were installed on the computer. The video camera was used to record the sessions of the procedure for subsequent verification of the data, especially the vocalizations made by the participants.

The software was developed to teach and test basic skills of reading and writing, allowing the programming of trials involving conditional discrimination procedures. For this, there was always the presence of a stimulus, with the function of auditory or visual sample, in the upper center of the screen, which determined the simultaneous choice of one of the stimuli with a matching function (from a maximum of three that were located at the bottom of the computer screen).

The application of the teaching programs constructed in ProgLeit ${ }^{\circledR}$ therefore enables the learning of arbitrary relationships, which are used for pairings between auditory and/or visual stimuli and for performing tasks. These tasks include the selection of stimuli, such as in the AB relationship (dictated word-figure), vocalization given a stimulus, such as in the $\mathrm{CD}$ relationship (naming of printed word), and the composition of a stimulus by smaller units than which compose it, such as the joining of syllables to form a printed word (CE relationship). During the application of the procedure, the computer registered the choices of the participant via the mouse, and all the naming responses were recorded via the keyboard by the experimenter.

The teaching program application procedures employed visual (printed figures, words 
Table 1

Characterization of the Learners

\begin{tabular}{|c|c|c|c|c|c|c|c|c|c|}
\hline \multicolumn{2}{|c|}{ Learner } & \multirow[t]{2}{*}{ Age } & \multirow[t]{2}{*}{$\begin{array}{l}\text { Medical } \\
\text { diagnosis }\end{array}$} & \multirow[t]{2}{*}{$\begin{array}{c}\text { Medical record } \\
\text { specifications }\end{array}$} & \multicolumn{4}{|c|}{ WISC-III } & \multirow[t]{2}{*}{ PPVT-R } \\
\hline \multicolumn{2}{|c|}{ Gender } & & & & Verb & Exec & Total & Classification & \\
\hline A1 & $\sigma^{\lambda}$ & $8 y$ & $\begin{array}{c}\text { Down } \\
\text { syndrome }\end{array}$ & $\begin{array}{l}\text { Difficulty } \\
\text { in speech }\end{array}$ & 53 & 68 & 57 & $\begin{array}{l}\text { Intellectually } \\
\text { disabled }\end{array}$ & $2 \mathrm{y} 1 \mathrm{~m}$ \\
\hline A2 & $\hat{0}$ & $11 y$ & $\begin{array}{c}\text { Down } \\
\text { syndrome }\end{array}$ & $\begin{array}{l}\text { Difficulty } \\
\text { in speech }\end{array}$ & 47 & 45 & 50 & $\begin{array}{l}\text { Intellectually } \\
\text { disabled }\end{array}$ & $2 \mathrm{y} 1 \mathrm{~m}$ \\
\hline
\end{tabular}

and syllables) and auditory stimuli (dictated words and syllables), corresponding to the verbal community. The printed words were selected by the experimenter from words present in the daily routine, consisting of three simple syllables, which followed the consonant-vowel syllabic pattern. Thus, the two words selected were "tapete" (carpet) and "fivela" (buckle), presented in block letters, in size 50 Arial font.

\section{General Procedure}

The teaching of naming of printed words proposed involved seven teaching steps that encompassed different types of relational tasks. These tasks could favor learning the repertoire of naming of printed words by previously exposing the participants to the training of basic repertoires. The teaching procedure followed an intra-subject design, in which pre- and post-test measures were applied around the intervention planned for the teaching of a pair of words.

The teaching consisted of the establishment of conditional relationships between dictated word-figure $(\mathrm{AB})$ and between dictated wordprinted word (AC). Conditional relationships of identity between figure-figure (BB) and between printed word-printed word (CC) were also taught; in addition to the significant relationships of naming figures (BD) and of echoing the auditory sample (AD), and constructing the printed word by selecting syllables (CE), as well as additional teaching of relationships between stimuli.

The teaching of the echoic verbal operant coupled with the teaching of the relationship of naming of figures was the differential in relation to previous studies (Almeida-Verdu et al., 2009;
Melchiori et al., 2000; Souza et al., 2013) and aimed to evaluate whether the improvement in speech intelligibility of the participants could influence the performance in the naming of the printed word. The emerging relationships were tested based on the selection between figureprinted word (BC) and printed word-figure (CB) and based on the response topography with the naming of the printed word (CD). Table 2 shows the steps of this procedure, with the description below.

The pre-test, the stage prior to the intervention, sought to evaluate whether the $B C$, $\mathrm{CB}$, and $\mathrm{CD}$ relationships had been established, without differential consequences for the responses, with a total of 28 trials ( $2 \mathrm{CD}$ trials +24 $\mathrm{BC} / \mathrm{CB}$ trials $+2 \mathrm{CD}$ trials). Therefore, this phase previously evaluated the formation of stimulus classes between the training words and had no learning criterion for the student to move forward to the following step. The two $\mathrm{CD}$ trials before and after the $\mathrm{BC} / \mathrm{CB}$ test (trials with only two comparison stimuli) sought to control whether the consistency in the repetition of the relationships could have taught the participants something.

The teaching was concentrated in seven steps, with differential consequences for the correct and incorrect responses of the learners. Each participant was subjected to all educational steps and could repeat them in an order that was not linear (P2, P5, P3 ...) to achieve the pre-established learning criterion for each step. This criterion was $100 \%$ correct responses in all trials (except for BD and AD due to the vocalization limitations of the participants), even if it was necessary to repeat the steps in a nonlinear way. 
Table 2

Types of Task Adopted in Pre- and Post-test and Teaching, Learning Criteria and Consequences Programmed for Responses

\begin{tabular}{|c|c|c|c|c|c|c|c|c|c|c|c|c|}
\hline \multirow{2}{*}{ Stages } & \multirow{2}{*}{$\begin{array}{c}\text { No. of } \\
\text { ttvs }\end{array}$} & \multicolumn{9}{|c|}{ Type of task } & \multirow{2}{*}{$\begin{array}{c}\text { Learning } \\
\text { Criteria }\end{array}$} & \multirow{2}{*}{$\begin{array}{l}\text { Consequence } \\
\text { programmed }\end{array}$} \\
\hline & & $\mathrm{AB}$ & $\mathrm{AC}$ & $\mathrm{BB}$ & $\mathrm{CC}$ & $\mathrm{CE}$ & $\mathrm{BD}^{*}$ & $\mathrm{BC}$ & $\mathrm{CB}$ & $\mathrm{CD}$ & & \\
\hline Pre-test & 28 & & & & & & & $\sqrt{ }$ & $\sqrt{ }$ & $\sqrt{ }$ & - & - \\
\hline $\mathrm{P} 1$ & 28 & $\sqrt{ }$ & & & $\sqrt{ }$ & & $\sqrt{ }$ & & & & $100 \%$ & $\sqrt{ }$ \\
\hline P2 & 26 & $\sqrt{ }$ & $\sqrt{ }$ & $\sqrt{ }$ & & & & & & & $100 \%$ & $\sqrt{ }$ \\
\hline P3 & 22 & $\sqrt{ }$ & $\sqrt{ }$ & & $\sqrt{ }$ & & $\sqrt{ }$ & & & & $100 \%$ & $\sqrt{ }$ \\
\hline P4 & 22 & $\sqrt{ }$ & $\sqrt{ }$ & & & $\sqrt{ }$ & & & & & $100 \%$ & $\sqrt{ }$ \\
\hline P5 & 22 & $\sqrt{ }$ & $\sqrt{ }$ & & & $\sqrt{ }$ & & & & & $100 \%$ & $\sqrt{ }$ \\
\hline P6 & 28 & $\sqrt{ }$ & $\sqrt{ }$ & & & & $\sqrt{ }$ & & & & $100 \%$ & $\sqrt{ }$ \\
\hline P7 & 18 & $\sqrt{ }$ & $\sqrt{ }$ & $\sqrt{ }$ & $\sqrt{ }$ & $\sqrt{ }$ & $\sqrt{ }$ & & & & $100 \%$ & $\sqrt{ }$ \\
\hline Post-test & 28 & & & & & & & $\sqrt{ }$ & $\sqrt{ }$ & $\sqrt{ }$ & - & - \\
\hline
\end{tabular}

Note. P: teaching step; A: dictated word; B: figure; C: printed word; D: naming; E: response of construction of words by syllables; * without systematic criteria of learning and with echoic training (AD); ttvs: attempts.

The teaching began with the $\mathrm{P} 1$ step in which the participant was exposed to the teaching of conditional relationships between the dictated word and figure $(\mathrm{AB})$, of the identity of words (CC) and of the naming of the figures (BD), with additional echoic teaching (AD). Each step had a specific teaching focus on one type of conditional relationship between stimuli or between stimuli and responses, however, included relationships complementary to the following steps. This arrangement of the teaching routine aimed to anticipate a greater stimulus control requirement, in a gradual way, on one hand; while on the other, the student could be motivated with the previously learned trials maintaining the occurrence of correct responses.

The P2 step, in addition to the relationship between the dictated word and figure (AB), included the relationship between the dictated word and printed word (AC) and identity between figures (BB). The $\mathrm{P} 3$ step was analogous to the P1 step, however, included the relationship between the dictated word and printed word (AC), recently trained in the P2 step. The P4 and $\mathrm{P} 5$ steps were identical in teaching relationships between the dictated word and figure (AB) and the dictated word and printed word (AC), however, were specific training for each word of teaching, with the increase in the copying by construction (CE) relationship. The P6 step exposed the participants to the audio-visual conditional ( $\mathrm{AB}$ and $\mathrm{AC}$ ) relationships and resumed the figure naming training (BD), with additional echoic teaching (AD). The P7 step exposed the participants to all the relationships between stimuli and between stimuli and responses trained in the previous steps.

The trials per step were designed with the same amount of relationships for each single word to be taught. The students would therefore be able to advance in the educational steps to be exposed to other tasks, even without responding correctly at the start of all the trials, so as to not let the teaching become repetitive and tiring. The gradual increase in complexity of the teaching focused initially on the AB tasks, as the learners presented the performance of $100 \%$ in the posttest (with different words) in the previous study (Gomes, 2014), which would facilitate the learning of the AC relationship. Next, identity tasks (BB or CC) were trained, as these are theoretically simple relationships, which would increase the likelihood of correct responses for the learner. The $\mathrm{BD}$ and $\mathrm{AD}$ relationships were taught in an unsystematic way, to minimize the vocalization limitations of the learners. Next, 
the EC relationships were taught, to increase the discriminative control by the minimal units that formed the words taught.

Half of the trials were programmed with capital letters and the other half with lowercase letters, in order to provide the transition between typefaces. The consequences programmed for the responses considered correct were praise and/ or sound effect and/or animated images lasting five seconds; and the consequence programmed for responses considered incorrect was the corrective phrase "No it's not!" and the return to the trial, with the opportunity to change the response choice. Each trial could be repeated five times, in order not to terminate the step.

In general, the structure of the procedure followed the teaching steps, which were composed of the trials in which the comparison stimuli were increasing in quantity on the computer screen, one by one, until there were three comparison stimuli. For the trials that involved responses of construction of words by syllables (CE), these could exceed the amount of three stimuli of construction at the bottom of the screen. The syllables were added one by one to until there were enough, or more, syllables to form the sample word as a way to model the correct answer.

Thus, for each type of task to be taught there was a gradual increase in the learning demands, as can be seen in Figure 1. Only one comparison stimulus could be selected according to the sample stimulus present.

The repetition of the same types of tasks, during the teaching steps, was a verification strategy for the presence of consistent responses to the teaching trials. This also mixed the tasks considered more difficult with those considered easier, which ensured a higher probability of correct responses in each step, as well as reinforcing the consequences.

The post-test was the step subsequent to the intervention, with the same structure as the pre-test applied to evaluate the occurrence of the formation of equivalence classes between the training words and, therefore, determine the effectiveness of the teaching of basic relational repertoires on the learning of the repertoire of naming printed words.

\section{Data Analysis}

The data were analyzed in order to verify the individual performance of the participants related to the formation of equivalence classes, in order to observe the change in the repertoire of naming two words isolated from the teaching of their basic relational skills. Thus, the frequency of responses was quantified before and after the intervention for the relational tasks between figures and printed words (BC and $\mathrm{CB}$ ) and naming of these words (CD).

The naming responses were categorized according to the correspondence (or not) with the conventions of the verbal community, which resulted in four categories: Total Naming: naming with point to point correspondence with the conventions of the verbal community; Partial Naming: naming with changes (e.g. tatepe or tabete instead of tapete), omission of phonemes or syllabic form (e.g., iela rather than fivela); Naming Without Correspondence: any response without convention with the verbal community (e.g., $u i$, rather than fivela); No reply: no response was emitted.

\section{Results}

The data of the participants allowed the evaluation of the performance in tasks that are part of the network of relationships of the repertoire of naming for the formation of stimulus classes between figures, dictated words and printed words. As a result, it was observed that the teaching of conditional relationships considered pre-requisite to the naming, such as the relationships of identity between stimuli (BB and $\mathrm{CC}$ ), of the selection of figures and printed words according to a auditory stimulus sample ( $\mathrm{AB}$ and $\mathrm{AC}$ ), of construction of printed word according to as the same word as the sample (CE), of naming figures (BD) and of echo according to the auditory sample (AD), increased the likelihood of the presence of emerging relationships between figures and printed words $(\mathrm{BC})$, printed words and figures (CB) and the naming of printed words (CD). The percentage of correct responses in the $\mathrm{BC}, \mathrm{CB}$ and $\mathrm{CD}$ relationships indicated the effectiveness 

on Word Naming in Children with Intellectual Disabilities.
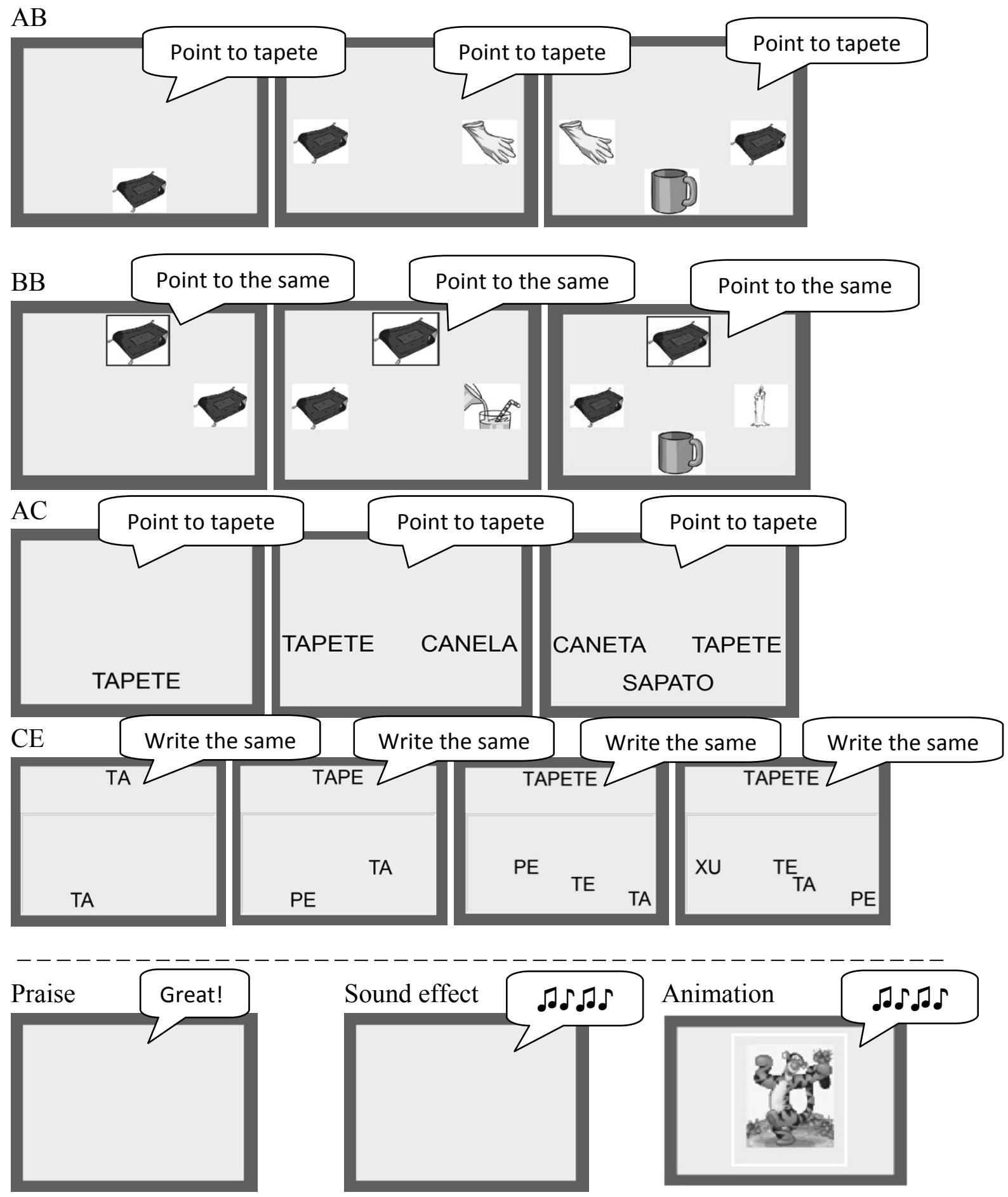

Figure 1. Representation of some of the tasks taught, and that shows the gradual inclusion of the comparison stimuli (from left to right) for the teaching of the relationships $\mathrm{AB}, \mathrm{BB}, \mathrm{AC}$ and $\mathrm{CE}$. The instructions for each type of relation are reproduced in the balloons. The lower part of the figure simulates the possible consequences for the correct response.

of the proposed intervention, as can be seen in Figure 2.

According to Figure 2, during the pre-test (dark gray bars), both participants presented low percentages of correct responses for the emerging relational tasks $\mathrm{BC} / \mathrm{CB}(\mathrm{A} 1: 37 \%$ and A2: $54 \%$ ) and for the naming of words $-\mathrm{CD}$ (both learners with zero performance), which showed the absence of formation of stimulus classes for the words "tapete" and "fivela". The 
Pre-test

A1
Post-test

A2

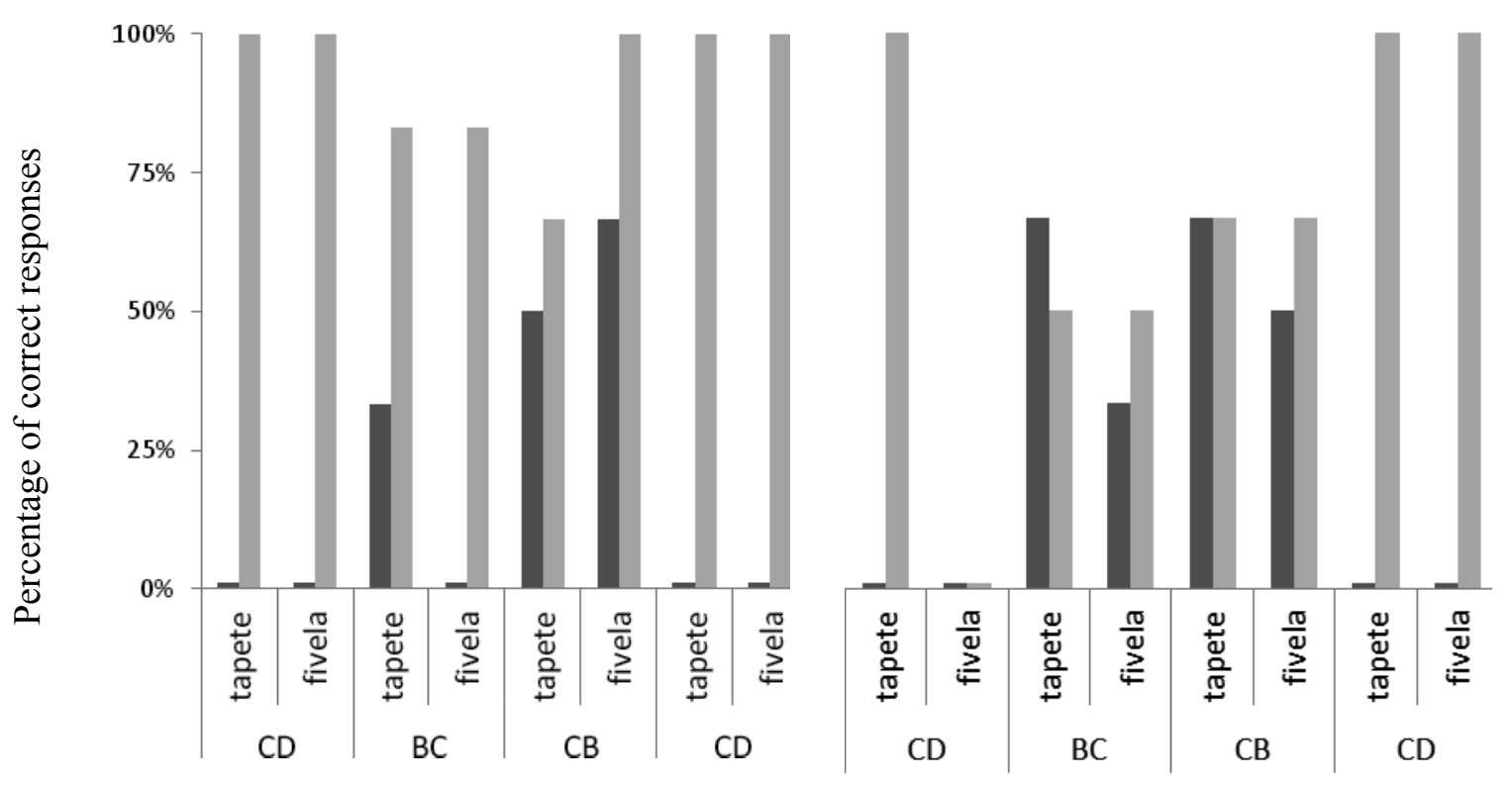

Figure 2. Percentage of correct responses of the participants in the pre- (dark gray bars) and post-test (light gray bars) for the teaching of basic repertoires.

$\mathrm{BC}$ and $\mathrm{CB}$ relationships required responses of stimulus selection and, with two choice possibilities, the responses considered correct probably occurred by chance.

Thus, the intervention was applied through the teaching steps to gradually teach the $\mathrm{BB}$, $\mathrm{CC}, \mathrm{BD}, \mathrm{AD}, \mathrm{AB}, \mathrm{AC}$, and $\mathrm{CE}$ relationships. The results of the participants, represented by the number of teaching step repetitions before obtaining the criterion of correct responses, are presented in Table 3; in this table, the most difficult relationship can be identified by the higher frequency of repetitions of the respective teaching step. In this case, the naming of figures (BD) and echoic (AD) behaviors are ignored, as these relationships did not follow the criteria of learning in a systematic way.

According to Table 3, the relationships involving the selection of the printed word when presented with the dictated word (AC) were the

Table 3

Teaching Step / No. of Repetitions / More Difficult Teaching Task

\begin{tabular}{|c|c|c|c|c|c|c|c|c|c|c|c|}
\hline A1 & $\mathrm{AB}$ & $\mathrm{AC}$ & BB & $\mathrm{CC}$ & $\mathrm{CE}$ & A2 & $\mathrm{AB}$ & $\mathrm{AC}$ & BB & $\mathrm{CC}$ & $\mathrm{CE}$ \\
\hline P1 & 2 & & & & & P1 & 5 & & & & \\
\hline P2 & & 1 & & & & P2 & & 7 & & & \\
\hline P3 & & 3 & & & & P3 & & 8 & & 8 & \\
\hline P4 & & 2 & & & 2 & P4 & & & & & 2 \\
\hline P5 & & & & & 1 & P5 & & 4 & & & 4 \\
\hline P6 & & & & & & P6 & & 6 & & & \\
\hline P7 & & 3 & & & 3 & P7 & & 7 & & & 7 \\
\hline
\end{tabular}


most difficult for the participants, requiring the greatest number of repetitions of up to 3 exposures for A1 and up to 8 exposures for A2, with A2 presenting more difficulty than A1.

It was perceived that, for A1, the teaching procedure, in general - teaching of relationships considered a prerequisite for the naming of words, such as in relating identical figures (BB), identical printed words $(\mathrm{CC})$, dictated word with its respective figures $(\mathrm{AB})$ or with printed words $(\mathrm{AC})$, naming figures (BD), echoing dictated words (AD) and forming the printed word when presented with the word itself, using smaller units such as syllables (CE) - was effective in changing the pattern of responses when presented with the tasks not directly taught, $\mathrm{BC}, \mathrm{CB}$ and $\mathrm{CD}$, for the two isolated words. During the posttest (light gray bars in Figure 2), A1 correctly read all $\mathrm{CD}$ trials and maintained performance, on average, above $80 \%$ for the $\mathrm{BC} / \mathrm{CB}$ trials.

The same teaching was not as effective for participant A2 when compared with the performance shown by A1, whose selection responses could not be explained as being by chance after the procedure. Participant A2 was exposed to a greater number of repetitions of the teaching sessions and, during the post-test, named " $t a$ pete" in the first two CD trials, obtained performance below $75 \%$ for the $\mathrm{BC} / \mathrm{CB}$ trials and read (partially) the other two CD trials correctly. The $\mathrm{BC} / \mathrm{CB}$ results indicated that participant $\mathrm{A} 2 \mathrm{did}$ not consistently establish equivalence relations between the figure and printed word stimuli, although achieved the criterion of learning during the teaching procedure. However, when comparing the percentage of correct responses obtained by A2 with his own initial repertoire, improvement was noted, that is, an increase in the percentage of correct responses.

The responses of naming printed words of the participants had different requirements according to the vocalization difficulties of each individual. Thus, both participants began the procedure unable to read the teaching words "tapete" and "fivela", emitting only monosyllabic vocalizations of the type "ui" or " $i$ ". In the post-test, it was observed that the two individuals had acquired the function considered correct for the naming of the taught words (i.e., issued topographically different vocalizations when presented with the two printed words, which were closer to the conventions defined by the verbal community). For A1 the difficulty in vocalizing was less than for A2, with the final vocal topography issued being "apete" and "fivela", while for A2 the topography produced was "pepete" and "favela". Figure 3 categorizes the naming performance of the participants for all the CD trials in the pre- and post-test.

From the categorization of the naming performance demonstrated in Figure 3, it can be seen that the teaching procedure improved
Pre-test

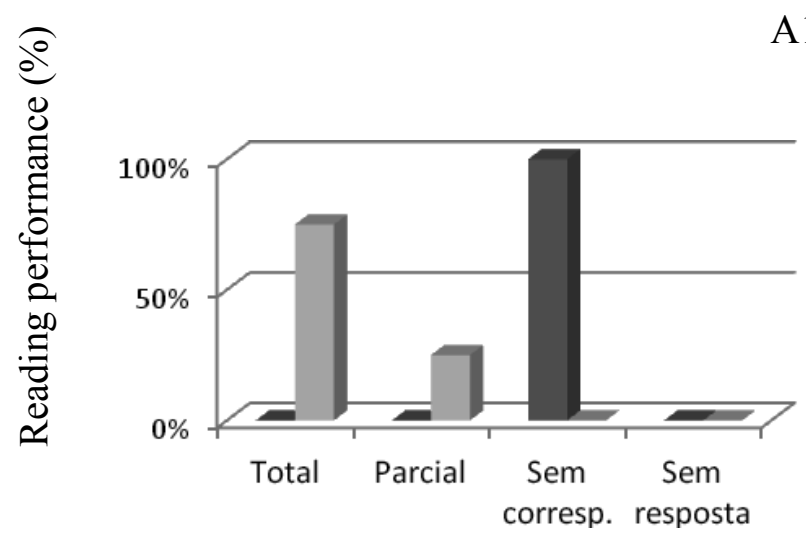

Post-test

A1

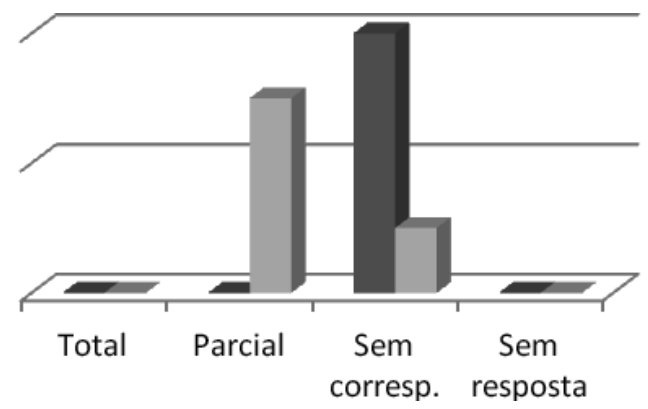

Figure 3. Categorization of the reading performance of the participants for the words taught in the Pre(dark gray bars) and Post-test (light gray bars). Total= Total; Parcial $=$ Partial; Sem corresp. $=$ Without correspondence; Sem resposta $=$ No response. 
the vocalization and intelligibility of the speech of the learners for their repertoires of naming printed words. Participant A1 achieved percentage of errors concentrated in words without correspondence $(100 \%)$ in the pre-test and after the teaching presented $75 \%$ of correct responses of naming the total word and only one word emitted partially $(25 \%$, with correct function). Participant A2, whose percentage of correct responses in the word total was zero, even in the post-test, after the teaching changed from a percentage of errors concentrated in words without correspondence $(100 \%)$ to a percentage of partially correct responses $(75 \%$ of the components of the words considered correct, as shown in Figure 2). Therefore, the procedure allowed the participants to modify the vocal topography issued when presented with the printed word, committing fewer errors, and presenting them ever closer to the conventions defined by the verbal community.

Thus, the change of the response patterns for the relationships considered emerging and related to the naming of printed words was demonstrated by individually comparing the pre- and post-test of the participants. Thus, the performances in the emerging relational tasks increased from $45 \%$ (mean, assessed in the pretest) to $77 \%$ (mean, assessed in the post-test) and the learners, who previously had zero repertoire of naming words, managed to read the two words taught.

\section{Discussion}

The teaching of discriminative repertoires prior to the establishment of equivalence classes, especially the teaching of echoic and naming repertoires, may have provided conditions for the formation of equivalence classes and extensions of stimulus control relationships for the naming of single words for the two participants with intellectual disabilities and with histories of failure to learn these repertoires. Previous studies used the same teaching program for participants with intellectual disabilities and showed advances in the teaching of word naming, however, there was a high number of repetitions of the sessions and trials (e.g. de Freitas, 2009, 2012; Melchiori et al., 2000).

Some studies performed with children with hearing deficiencies have shown that when they are able to accurately read (the graphemes working as clues for the emission of the phoneme defined as correct) the control exerted by the printed word extends to the figure after strengthening of the classes of equivalence between figure, dictated word and printed word. Thus, children start to emit more precise vocalizations in the presence of the figure (AnastácioPessan et al., 2015; Lucchesi, Almeida-Verdu, Buffa, \& Bevilacqua, 2015). Similarly, in this study, when the participants began to emit more accurate vocalizations in the naming of figures after the echoic training, the control exercised by the figures, after the formation of equivalence classes, was exercised by the printed words.

De Freitas (2012) also used echoic teaching with a child with intellectual disabilities, as a timely and remedial teaching procedure, which provided evidence of its possible effectiveness for the occurrence of the naming of printed words for this individual. From this, the present study aimed teach a series of discriminative repertoires that compose part of the reading network (as in other studies) and included the echoic into this network of educational relationships.

Participants A1 and A2 evolved rapidly during the teaching procedure, with the gain of the relational repertoire, which was guaranteed by the learning criteria, and began to functionally read the taught words "tapete" and "fivela". However, A2 showed lower performance for the formation of stimulus classes during the tests, although, having repeated the teaching sessions more often, he achieved the pre-established learning criteria.

Some articulatory problems of people with Down syndrome were taken into account (see Barata \& Branco, 2010) for the function of naming of printed words of the participants to be considered correct. Vocal responses that, while not having point to point matching with the conventions defined by the verbal community, were topographically different (response when presented with FIVELA and when presented with 
TAPETE), which had consistency throughout the trials and that had components of the correct response were considered as the correct function of naming words. In this case, the articulation errors that occurred may simply have been the best articulation possible. Similarly, the difficulty in emitting correct vocalizations is also observed in the analysis of vocalizations of children with cochlear implants (see Almeida-Verdu et al., 2009; Almeida-Verdu, Matos, Battaglini, Bevilacqua, \& de Souza, 2012; Golfeto, 2010).

As the word imitation teaching procedures (echoic verbal operant) have been effective in the subsequent response of naming figures in populations with hearing impairments (AlmeidaVerdu et al., 2009; Souza et al., 2013), to increase the training of $\mathrm{BD}$ and $\mathrm{AD}$ relationships for the network of equivalence relations facilitated the naming of the participants when presented with the printed word, through the extension of control exercised by the figure over the printed word.

The repetitions of the teaching sessions for both participants still occurred quite frequently and in higher quantities for one of the participants (A2), who had greater difficulty verbalizing. The amount of words taught, only two, hindered a broader evaluation of the word naming repertoire of the participants. Other limitations were found, such as the fact that the emerging relationship tests occurred in extinction and they hindered the measurement of the establishment of equivalence classes, especially for participant A2. The absence of consequences signaling the correct or incorrect responses in the tests made $\mathrm{A} 2$, in the test situation in extinction, to randomly select the responses and seek the consequences provided during the teaching, to raise his hand as a form of greeting, push the computer desk and emit vowel sounds characteristic of irritation.

The tests performed in extinction had the purpose of verifying the accuracy of the emerging relationships, in a way that the use of reinforcing consequence could not teach the relationships verified to the individual. This methodological choice of applying tests in extinction without a gradual preparation for the withdrawal of the reinforcing consequences differs from other studies in which the reinforcing consequences applied were contingent on the participation of the individual, not their performance (e.g. Resende, Elias, \& Goyos, 2012; Zaine, Domeniconi, \& de Rose, 2014), or these consequences were specifically used for the choices considered correct (e.g. Domeniconi, 2002; Schusterman \& Kastak, 1993; Velasco, Huziwara, Machado, \& Tomanari, 2010). Another way to plan the verification of learning is through alternating between reinforced and unreinforced trials and gradually moving from reinforcing consequences to the tests in extinction (e.g. Medeiros \& Silva, 2002; Sidman et al. 1989), in order to prepare the participants for the situation of the test of emerging relationships.

Domeniconi (2002) argues that the performance of tests that maintain reinforcements systematically programmed for the performance considered correct seeks to prevent the insertion of an intervening variable (non reinforcement for the responses) in the test situation. Some of the reasons given by the author for the use of tests with programmed reinforcement are the prevention of avoidance reactions and motivational decreases for the individuals, to avoid the interference of other events and to increase the likelihood of engagement of the participants in the test task, as these individuals continued in the same conditions of reinforcement during the application of the entire procedure. However, when the test occurs in extinction the hint of maintenance or not of a response is not presented and this complicates the performance of the participant. It is probably for this reason that the test performance of A2 was not as good as in the teaching stage.

Considering the gradual nature of the teaching and the learning difficulties of the participants with intellectual disabilities, trials with uppercase and lowercase letters were mixed as a way to expose and prepare the learners for the two types of letters. This decision was based on de Freitas (2012), who showed that the use of textual stimuli spelled in capital letters provided gains in the relational skills, by increasing the discriminatory abilities of the learners with 
intellectual disabilities. Another reason was that, in the special school, the study participants were exposed to some teaching materials with lowercase letters.

In summary, with this study, the effectiveness of the teaching of repertoires prior to the establishment of equivalence classes was demonstrated, as the two words taught began to establish stimulus control in the verbal behavior of the participants

\section{Final Considerations}

In general, gradually structured teaching, with learning criteria established during the steps of the procedure, helps to provide increased effectiveness of the teaching and learning. These repertoires are established with the repetition of teaching and with the scope of the criterion, which enables greater accuracy and retention of previously learned repertoires, though does not necessarily guarantee the emergence of new relationships.

Thus, a procedure that uses conditional discriminations in a gradual way (from more simpler relationships - identity between stimuli, pairing between dictated words and figures - to more complex relationships - pairings between figures and printed words, construction of words from smaller units) would prepare the teaching of basic skills for the subsequent acquisition of a more complex repertoire, such as reading comprehension. The gradual teaching of basic skills provided the learning of this repertoire and validated a simple teaching program divided into small steps. This therefore facilitated the formation of equivalence classes and allowed the naming of isolated words.

Thus, it is recommended that more work is done with people with intellectual disabilities and speech difficulties, in order to expand the teaching procedure with more words (both teaching and generalization), with more participants and particularly with systematic criteria in the trials related to expressive behavior (BD and $\mathrm{AD}$ relationships). It is also suggested, for future studies, changes in the test that scrutinizes the acquisition of the relational repertoire, with the inclusion of reinforcing consequences to increase the participant's adherence at the end of the procedure.

\section{References}

Almeida-Verdu, A. C. M., Bevilacqua, M. C., de Souza, D. G., \& Souza, F. C. (2009). Imitação vocal e nomeação de figuras em deficientes auditivos usuários de implante coclear: Estudo exploratório. Revista Brasileira de Análise do Comportamento, 5(1), 63-78.

Almeida-Verdu, A. C. M., Giacheti, C. M., Lucchesi, F. M., Freitas, G. R., Dutka, J. C. R., Rovaris, J. A., \& Marques, P. F. (2015). Apraxia e produção da fala: Efeitos do fortalecimento de relações verbais. Revista CEFAC, 17, 974-983.

Almeida-Verdu, A. C. M., Matos, F. O., Battaglini, M. P., Bevilacqua, M. C., \& de Souza, D. G. (2012). Desempenho de seleção e nomeação de figuras em crianças com deficiência auditiva com implante coclear. Temas em Psicologia, 20(1), 189-202.

Anastácio-Pessan, F. L., Almeida-Verdu, A. C., Bevilacqua, M. C., \& de Souza, D. G. (2015). Usando o paradigma de equivalência para aumentar a correspondência na fala de crianças com implante coclear na nomeação de figuras e na leitura. Psicologia: Reflexão e Crítica, 28(2), 365-377.

Barata, L. F., \& Branco, A. (2010). Os distúrbios fonoarticulatórios na Síndrome de Down e a intervenção precoce. Revista CEFAC, 12(1), 134-139.

Bevilacqua, M. C., \& Souza, D. G. (2012). A criança com deficiência auditiva na escola: Sistema de $F M$. São Carlos, SP: Cubo.

Catania, C. A. (1999). Aprendizagem: Comportamento, linguagem e cognição (D. G. de Souza, Trans.). Porto Alegre, RS: Artmed.

De Freitas, M. C. (2009). Programação de ensino de leitura e escrita para crianças com deficiência mental (Master's thesis, Programa de Pósgraduação em Educação Especial, Universidade Federal de São Carlos, SP, Brazil).

De Freitas, M. C. (2012). Construção de um programa de ensino de pré-requisitos de leitura e escrita para pessoas com deficiência intelectual (Doctoral dissertation, Programa de Pós-gradua- 
ção em Psicologia, Universidade Federal de São Carlos, SP, Brazil).

De Rose, J. C. C. (1993). Classes de estímulos: Implicações para uma análise comportamental da cognição. Psicologia: Teoria e Pesquisa, 9(2), 283-303.

De Rose, J. C. (2005). Análise comportamental da aprendizagem de leitura e escrita. Revista Brasileira de Análise do Comportamento, 1(1), 29-50.

De Rose, J. C., \& Bortoloti, R. (2007). A equivalência de estímulos como modelo do significado. Acta Comportamentalia, 15(3), 83-102.

De Rose, J. C., de Souza, D. G., Rossito, A. L., \& de Rose, T. M. S. (1989). Aquisição de leitura após história de fracasso escolar: Equivalência de estímulos e generalização. Psicologia: Teoria e Pesquisa, 5, 325-346.

De Souza, D. G., \& de Rose, J. C. (2006). Desenvolvendo programas individualizados para o ensino de leitura. Acta Comportamentalia, 14(1), 77-98.

Domeniconi, C. (2002). Análise de controle restrito de estímulos na aprendizagem de leitura de palavras por individuos com Sindrome de Down (Master's thesis, Programa de Pós-graduação em Educação Especial, Universidade Federal de São Carlos, SP, Brazil).

Dunn, L. M., \& Dunn, L. M. (1981). Peabody Picture Vocabulary Test: Revised. Circle Pines, MN: American Guidance Service.

Fonseca, M. L. (1997). Diagnóstico de repertórios iniciais de leitura e escrita: Uma análise baseada na concepção de relações de equivalência (Master's thesis, Programa de Pós-graduação em Educação Especial, Universidade Federal de São Carlos, SP, Brazil).

Golfeto, R. M. (2010). Compreensão e produção de fala em crianças com surdez pré-lingual usuárias de implante coclear (Doctoral dissertation, Programa de Pós-graduação em Educação Especial, Universidade Federal de São Carlos, SP, Brazil).

Golfeto, R. M., \& de Souza, D. G. (2015). Sentence production after listener and echoic training by prelingual deaf children with cochlear implants. Journal of Applied Behavior Analysis, 48(2), 363-375. doi:10.1002/jaba.197

Gomes, M. L. de C. (2014). Ensino de leitura com diferentes treinos discriminativos a aprendizes com deficiência intelectual (Master's thesis, Programa de Pós-graduação em Psicologia, Universidade Federal de São Carlos, SP, Brazil).

Lucchesi, F. M., Almeida-Verdu, A. C. M., Buffa, M. J. M. B., \& Bevilacqua, M. C. (2015). Leitura e inteligibilidade da fala: Efeitos de ensino programado com crianças usuárias de implante coclear. Psicologia: Reflexão e Crítica, 28(3), 500-510.

Medeiros, J. G., \& Silva, R. M. F. (2002). Efeitos de testes de leitura sobre a generalização em crianças em processo de alfabetização. Psicologia: Reflexão e Crítica, 15(3), 587-602.

Melchiori, L. E., de Souza, D. G., \& de Rose, J. C. (2000). Reading, equivalence and recombination of units: A replication with students with different learning histories. Journal of Applied Behavior Analysis, 33, 97-100. doi:10.1901/ jaba.2000.33-97

Neves, A. J., \& Almeida-Verdu, A. C. M. (2014). Efeitos de ensino envolvendo equivalência entre palavra ditada, palavra escrita e objeto sobre a inteligibilidade da fala em adolescente com hipoplasia cerebelar. Revista CEFAC, 16(4), 1340-1350.

Pereira, V. A., \& Almeida-Verdu, A. C. M. (2012). Avaliação do ler e do escrever em surdos pela Língua Brasileira de Sinais (Libras). Psicologia: Teoria e Prática, 14(2), 15-27.

Quinteiro, R. de S. (2014). Aquisição de discriminações auditivo-táteis e emergência de leitura recombinativa em Braille (Doctoral dissertation, Programa de Pós-graduação em Psicologia, Universidade Federal de São Carlos, SP, Brazil).

Resende, A. A. C., Elias, N. C., \& Goyos, C. (2012). Transferência de funções ordinais através de classes de estímulos equivalentes em surdos. Acta Comportamentalia, 20(3), 317-326.

Rosa, A. B., Filho, de Rose, J. C., de Souza, D. G., Hanna, E. S., \& Fonseca, M. L. (1998). Aprendendo a ler e a escrever em pequenos passos [Computer software].

Santos, S. de L. R. (2012). Caracterização de desempenhos envolvidos na leitura e na escrita em crianças com deficiência auditiva (Master's thesis, Programa de Pós-graduação em Psicologia do Desenvolvimento e Aprendizagem, Universidade Estadual Paulista Júlio de Mesquita Filho, Bauru, SP, Brazil). 
Schusterman, R. J., \& Kastak, D. (1993). A California see lion (Zlophus californianus) is capable of forming equivalence relations. The Psychological Record, 43, 823-839.

Sidman, M. (1977). Teaching some basic prerequisites for reading. In P. Mittler (Ed.), Research to practice in mental retardation: Vol. 2. Education and training (pp. 353-360). Baltimore, MD: University Park Press.

Sidman, M.(1994). Equivalence relations: A research history. Boston, MA: Authors Cooperative.

Sidman, M., \& Tailby, W. (1982). Conditional discrimination vs. matching to sample: An expansion of the testing paradigm. Journal of the Experimental Analysis of Behavior, 37, 5-22.

Sidman, M., Wynne, C. K., Maguire, R. W., \& Barnes, T. (1989). Functional classes and equivalence relations. Journal of the Experimental Analysis of Behavior, 52(3), 261-174.

Souza, F. C., Almeida-Verdu, A. C. M., \& Bevilacqua, M. C. (2013). Ecoico e nomeação de figuras em crianças com deficiência auditiva pré-lingual com implante coclear. Acta Comportamentalia, 21(3), 325-339.
Stromer, R., Mackay, H. A., \& Stoddard, L. T. (1992). Classroom applications of stimulus equivalence technology. Journal of Behavioral Education, 2, 225-256.

Velasco, S. M., Huziwara, E. M., Machado, A., \& Tomanari, G. A. Y. (2010). Associative symmetry by pigeons after few-exemplar training. Journal of the Experimental Analysis of Behavior, 94(5), 283-295.

Wechsler, D., \& Figueiredo, V. L. M. (2002). WISCIII: Escala de Inteligência Wechsler para crianças. Adaptação brasileira da $3^{a}$ edição. São Paulo, SP: Casa do Psicólogo.

Zaine, I., Domeniconi, C., \& de Rose, J. C. (2014). Simple and conditional discrimination and specific reinforcement in teaching reading: An interventional package. The Analysis of Verbal Behavior, 30, 193-204.

Recebido: $15 / 05 / 2015$

$1^{a}$ revisão: 29/10/2015

$2^{a}$ revisão: $21 / 01 / 2016$

Aceite final: 21/02/2016 